\title{
A New Course on Management Education Introduced by a New Instructional Design Model
}

\author{
Nabil Mehddeb
}

\begin{abstract}
This paper presents an introduction oftwo new educational technologies on management education: A course and its dedicated instructional design model. The course isentitled: Innovation Engineering (InnovEng) and the instructional design modelis named: Concurrent Design by Scenarios $(C D b y S)$. InnovEng deals with tools and methods used for radical innovation. It is injected for the first time into the curriculum of management studentsat the management department of Annaba University in Algeria between July 2010 and December 2012. Due to the context specificity of this university, we have created and applied $C D b y$ Smodel through 5 semesters in 8 classes capitalizing 195 students. The Results show that students of management have a keen interest in this kind of course. They were attracted by this type of pedagogy and they showed a confirmed hyperactivity more than they do in other classic courses delivered in management schools. The use of CDbySmodel allowed us to improve flexibility in the learning process management, a successful adoption of new tools and methods of radical innovationand a high degree of reactivity with the respect of the uncertain context which the course has been developed.
\end{abstract}

Index Terms - Innovation engineering, concurrent design by scenarios.

\section{INTRODUCTION}

Today, radically innovate or create something new not only concern artists or inventors. Leaders must possess this quality and control it. Given that, we will not wait long to see this sought skill injected into the curriculum of business schools [1]-[3].

Innovation Engineering (InnovEng) is an area of research under construction interested in piloting innovative projects since their early phases. Our research showed us that in 2010 , this type of material is not taught to the students of management worldwide, and especially in Algeria, it is absent from the curricula of engineers' schools. To effectively manage innovative projects, and through Innovation Engineering, specific tools and methods are used. A special scale has been developed also to measure the degree of innovation.

In our case, Innovation Engineering is an innovative material that is designed to increase the student's skills of invention (creation of something new). We call them: RadicalInnovation Skills. Professor Bernard Yannou from EcoleCentrale Paris is a pioneer in research and education in

Manuscript received February 12, 2014; revised April 30, 2014. Thi work was supported in part by the Algerian Ministry of Higher Education and Scientific Research Fellowship under PNE Program 2008-2010.

N. Mehddeb is with the Management Department of Annaba University and with Economical Environment Department of Algiers Management School, Algeria (e-mail: mehddeb.nabil@ gmail.com). thefield of innovation engineering applied to high schools of engineering [4], [5]. He divides disciplines that claim education and the development of innovation in three: Management Sciences in business schools, art and creation in industrial design schools and design sciences in engineering schools [6].

The novelty of ourcourse is that we applied methods and tools designated for engineering students to management students taking into account the difference in the epistemology and knowledge on both disciplines.

To do this, we have also developed a new instructional design model in response to Management Department context of Annaba University in Algeria. We call it: Concurrent Design by Scenarios (CDbyS).

In what follows, we will cite aprior work to both disciplines: management education and instructional design models. Then, we will show some commentaries about these two domains in relationship withthe Annaba University context and Radical Innovation Skills and we will give proposals to overcome some shortcomings. Next, we will present two methodologies: The first concerning the design and implementation of CDbyS model, and the second concerns the design and implementation of the new course InnovEngat the management department of Annaba university in Algeria. After that, we will show the results of the course as well as its dedicated instructional design model.Finally, we conclude this paper with the results and their implications and will indicate the limits of our work.

\section{LITERATURE REVIEW}

\section{A. Management Education}

Many researchers have dealt with management education worldwide (see Table I).

TABLE I: MAIN AUTHORS ON MANAGEMENT EDUCATION WORLDWIDE

\begin{tabular}{ll}
\hline \hline Area & Author \\
\hline Management education in U.K & Holman 2000 [7] \\
A survey on management education on 9 & Byrt 1989 [8] \\
countries & Mintzberg 2005 \\
Comparison between managers and & {$[2]$} \\
MBA's & Garel\&Godelier \\
Management Education in France & 2004 [9] \\
& Biencourt\&al. \\
French Deans' report & 2007 [10] \\
Comparison between management & Nioche 2007 [11] \\
education in U.S.A and France & Alon\&McIntyre \\
Management education in China & 2005 [12] \\
Management education in E.U & Tuning 2009 [3] \\
\hline \hline
\end{tabular}


If therootsofmanagement educationextend to thetime of the training of officials ofthe Prussianadministration in the 16th century, we cansay thatthe currentinfluence ofmanagement educationin the worldcomes from the UnitedStatesin the 20thcenturyat the timeof the two opponent'sschools: Harvard and Carnegie [2].

\section{B. Instructional Design Models}

If the Learning Theory is built on the basis of descriptive theories to help us understand the phenomenon of learning and its interactions within and between systems, so that Instructional Theory orInstructional Design Theory which will includes prescriptive theories that seek to give us manuals to design and manage Instructionat three levels: micro, meso and / or macro [13], [14].

Many models have been created sincethe Second World War [15], in order to boost the skills of a large number of soldiers in arms and war. We can also find attempts of this discipline starting in the early twentieth century with works such as Bobbitt in 1918 [16]. Since, among the most common of these models, we can mentionthose of Gagné \& Briggs [17], Diamond [18], Romiszowski [19], Brien [20], Dick \& Carey [21], US Marine Corps [22] and Smith \& Ragan [23].

After the increasing tendency of the number of instructional design models, several studies were developed to compare and classify these models according to different parameters. Three of the most famous of these studies are those of Reigeluth \& Carr-Chellman [24], Edmonds, Branch $\&$ Mukherjee [25] and Gustafson [26]. The following TableII shows the contribution of the 18 most relevant authors in the field ofinstructional design models.

\begin{tabular}{cll}
\multicolumn{2}{c}{ TABLE II: CONTRIBUTION OF AUTHORS } \\
\hline \hline Year & Author(s) & Contribution \\
\hline 1974 & Snelbecker & Concepts Adjustment \\
1979 & Gagné\& Briggs & Proposed a model \\
1981 & Romiszowski & Proposed a model \\
1983 & Reigeluth & Taxonomy \\
1989 & Diamond & Proposed a model \\
1991 & Brien & Proposed a model \\
1994 & Edmonds, Branch, Mukherjee & Taxonomy \\
1996 & Gustafson & Taxonomy \\
1996 & Braden [27] & Comments(taxonomy) \\
1998 & Diamond & Proposed a model \\
1999 & Reigeluth & Taxonomy \\
2004 & United States Marine Corps & Proposed a model \\
2005 & Dick \& Carey & Proposed a model \\
2005 & Smith \& Ragan & Proposed a model \\
2006 & Dessus & Taxonomy \\
2009 & Reigeluth & taxonomy \\
\hline \hline & & \\
\hline 19 & & \\
\hline
\end{tabular}

\section{COMmentaries, ShORTCOMINGS AND Proposals}

\section{A. Commentaries}

Based on the literature review indicated above, we can make the following comments:

\section{1) Instructional design models \& Annaba University context}

It is clear that the models mentioned above follow a sequential approach in their design of instruction. This is built on assumptions such as total involvement of the top management of educational institutions in the design of this instruction and work in collaboration with all stakeholders in management education and in particular: companies.

The conditions of implementation of the InnovEngcourse were not favorable:

- The management department administrators at the University of Annaba totally disconnected from our work.

- The students are derived from modest bachelor (management or science) in most of them. Their reactions to this course we were throughout the implementation: unpredictable.

- This course is presented to students belonging to different classes, with different profiles, different expectations, heterogeneous levels and target different learning outcomes.

- The lack of adequate training facilities (laboratories, workshops, digital platform, documentation and internet connection).

- No full involvement of companies in this course.

With all these ingredients, is the sequential design the best way to design our course?

\section{2) Management education \& radical innovation skills}

The remarkable work of $\mathrm{H}$. Mintzbergon the classification ofmanagerial skills [28], Yannou and Bigandonthe skills of industrial or project manager [1], and finally Tunin gprogram [3], show thatinthe skills expectedof a manager or a leader, the creativity andability to innovateradicallyhave notreceived a sufficientexploration.

\section{B. Shortcomings}

Based on the comments indicated above, we can distinguish two shortcomings:

- The inadequacy of the sequential design to the high uncertainty context of management department of Annaba University.

- The neglect of Radical Innovation Skills on Management Education.

\section{Proposals}

To address these two shortcomings, we have created the new course on management education: InnovEng and its dedicated instructional design model: CDbySwith the methodology mentioned below.

\section{Methodology}

\section{A. CDbyS Model}

\section{1) Design}

We developed the model shown in Fig. 2 for the design, development, implementation, control and improvement of the course: Engineering innovation for management students at the University of Annaba. We relied on:

- The experience we have gained in EcoleCentrale 
ParisnearProfessor Bernard Yannou from 2008 to 2010 during the development of this material for the 3rd year CISI Design and Industrialization of Innovative systems [29], 2nd year CIPS Design and Innovation of products and Services.

- Ariane Reform for the development of curriculum forCentrale's students [30], [31].

- The basis of this model is the generic ADDIEmodel [22] as shown in Fig. 1, except that it has not been applied sequentially but concurrently [32]-[34].

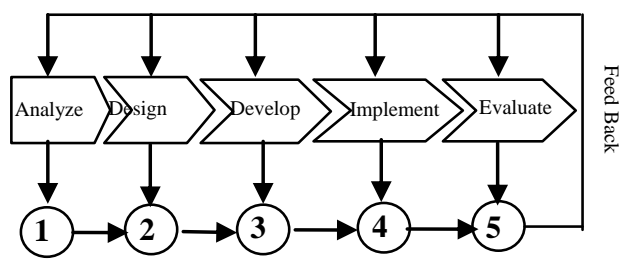

Fig. 1. ADDIE model.

Given the volatile context in which we were forced to deal with, we needed to keep a great margin of maneuvers to make the necessary changes at the right time against the scenario that arises when we deploy on the groundof the new course. We therefore make necessary corrections in different phases: analysis, design, development, implementation and evaluation in $360^{\circ}$ directions with the quantity and quality needed, without an a priori sequential order of different phases. This allows us to control the educational process towards the approved goals already agreed (goal 1, goal 2,...., goal $n$ ).

It should be noted here that the author was the sole provider of the course of innovation engineering for the students of management from the beginning to the end of thiseducational adventure. He used the CDbyS model which is based on concurrent engineering in order to improve the course: Innovation EngineeringInnovEng and CDbyS model itself with a continuous and synchronized manner. This was imperative because he ignores the reactions of students, colleagues (teachers) and management department staff administrators to deal with this new course.

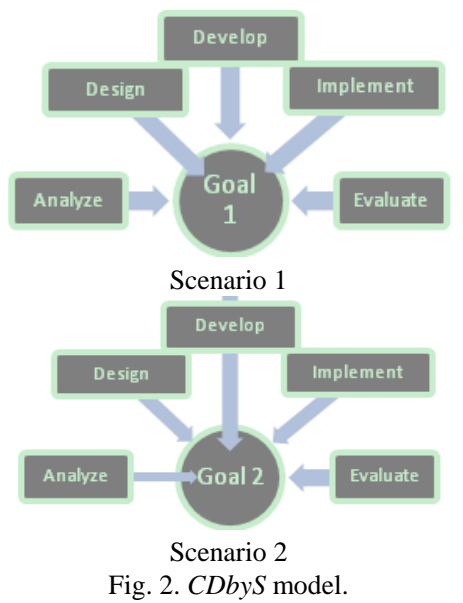

\section{2) Implementaion}

Although they attended the same course, but the students of each degree and each specialty acquired different learning outcomes. This was possible thanks to the gameof changingingredients allowed by $C D b y S$ model.
In the academic year 2010/2011, we have set the bar high as well as with emphasized the number of tools that must be learned and modeling of prototypes. So we can say that to achieve this goal (goal 1), we used a large substance of design and implementation since it is the first application of this course at the University of Annaba (see Fig. 3).

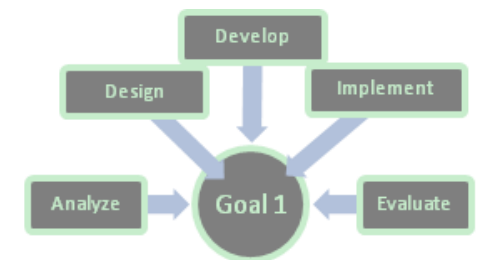

Fig. 3. CDbyS model with large substance of Design and Implementation.

For the academic year 2011/2012, we lowered the bar by simply looking at some tools and compare them to each other, without prototypemodeling. We focusedon analyzing the learningsituation at the management department of Annaba University and developed teaching so that it is less intensive forstudents during this academic year. This will be the goal 2 (Fig. 4).

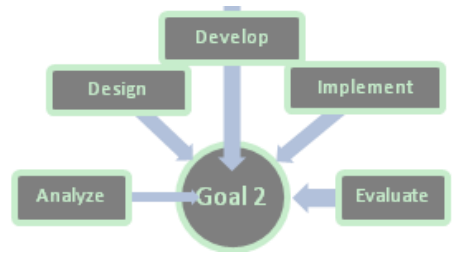

Fig. 4. 2CpS model with a largesubstance of analysis and development.

Then during the academic year 2012/2013, we returned to the charge, and we wanted to set up competing groups against each other, to provide us innovative prototyped ideas (return to goal 1). So we focused on the two concurrent phases: design and implementation (Fig. 3).

The same game of changing ingredients has been applied to one class to another, taking into account their different levels and heterogeneous expectations. Between Bachelor degree and Master degree or between different master specialties, we have made changesto the content provided on these classes after using another large substance of the analysis phase and the development phase as shown in Fig. 4

\section{B. InnovEng Course}

\section{1) Design}

The aim of the course: Innovation Engineering is to enable management students to acquire a high degree of mastering tools and methods used in the innovation of products and services such as: Value Analysis, Functional Analysis, TRIZ method, APTE method, RID method, Brainstorming, mind maps, SCOS method and Blue Oceans Strategy.

We used for this course a mix of different teaching methods such as: Case studies, slideshows, audios, videos, projections, role play, simulations and specific software used for innovation, modeling and simulation.

The objective of this course is that students will be able to realize a product or service innovation by using tools and methods of Creativity and Innovation, taking into account the impact of their environment in the process of innovation.

This course addresses the brain. Based on the results of the 
1999-2010 Tuning Program on Business and Management Education[3], it aims to improvethe students' skills in the following areas:Languages (EN / FR), communication, learn to learn, mastering ICT, the ability to provide new ideas, as well as analyzes and synthesize the basis of a scientific research necessary to pursue $\mathrm{aPhD}$.

The design of the course can be resumed on the following steps:

- We begin with an introductory session where we discussed with students to assess their level and expectations. Then we distributed a survey on: the average and the specialty of baccalaureate , passing average to the third year Bachelor, accumulated credits in the first or second year Bachelor, level of language skills, hobbies, artistic experience, degree of masteringITC and communication skills individually or in groups. After that, I introduce them to the course summary by explaining the content and chronology of this new material, its expected learning outcomes and the assessment's criteria.

- Next, we continue with a presentation of different tools and methods for the innovation of products or services and for steering the innovative projects. We have applied them to products and services made by industries or put on markets near the University of Annaba. At this stage, students can handle, separate or assemble these products with their own hands. Tasks that students have to accomplish as a part of a mini-projectare explained in the Innovation Feasibility File (IFF).

- Each mini-project was composed of two phases: oral and written. The evaluation criteria of audio-visual presentation are: degree of deeping and investigation, degree of relevance and objectivity, degree of scientific rigor and the level of mastering technological tools and communication skills. The evaluation criteria of written presentation are: the methodology used, the scientific value of the content, spelling and language style, the aesthetic side of the manuscript and Intermediary Design Objects IDO's (or prototype hardware as a proof of concept).

- The goal is to train students to master 9 methods and 22 support tools to innovate or steer innovative projects (and also to master a large number of professional software).

- During this course, we present the Radical Innovation Design ${ }^{\circledR}$ Method developed by Professor Bernard Yannou in EcoleCentrale Paris and we apply it to steer the students innovative projects [4]-[6], [35].

- When we have distributed the mini-projects to students, we gave the same project for two or three competing groups so that the best group gives us the best project. We invested in a challenge and competition between these groups.

\section{2) Implementation}

This course has been taught for eight separate classes during the academic years 2010/2011, 2011/2012 and $2012 / 2013$ with some changes from year to year. Table III shows the classes that were trained during these three academic years.

\section{Academic Year 2010/2011}

- The bachelor class: Entrepreneurship management
Students of this class had a very lowlevel of skills and knowledge except 3 of them. We can say we were facing a "special class" assecondary school,where students tend to be agitated and have a "spirit of the street".The number of students is 36 .

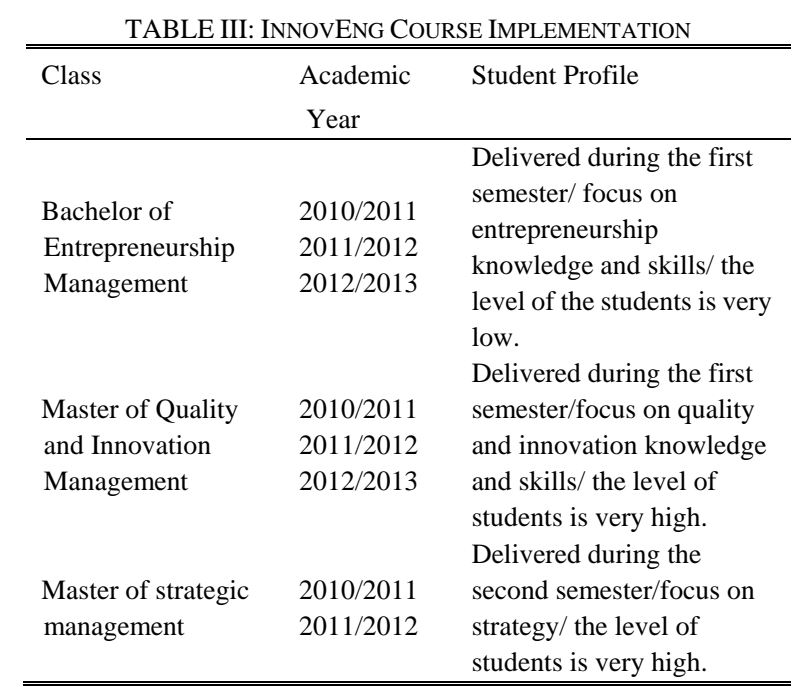

The theme for this year's mini-projects explained by their Innovation Feasibility File is: Toys.

There are Ten groups of three students and one group of six students. They were competitive groups to show me the most innovative toy's concept. The results of these groups are in the results section.

- The master class: Quality and innovation management

Students enrolled in this class are the best of the bachelor promotion 2009/2010 at Annaba University in Management field. 23 students had attended this course.

Each group of three to four students had to choose one of the mini-projects mentioned in the following list: A technique for measuring the number of movement in the Muslim prayer, innovative kitchen tool, a technique to motivate reading, a technique to accelerate reading a book, innovative chair, a children's toy, a surgical tool, a device for the disabled people, tools or appliances for gerontology, gardening tool, masonry and construction tool, agricultural tool or machine, a desktop tool, a new alarm system and a beauty product.

- The master class: Strategic management

Students enrolled in this Class are also the best of the bachelor promotion 2009/2010 in the field of Management at the University of Annaba. 25 students had attended this course.

The difference between the two Master Classes is that in the first we preserve the same design described in the section: design of the course InnovEng, but we focus on the definition of innovation and a case studies of product or a service innovation, but in the second we focus on the creativity tools and innovation strategies such asBlue Oceans Strategy.

The novelty in this class that we showed them the same list of mini-projects as their counterparts of quality and innovation management, but we divided work within the group, telling everyone the tasks he/she must performfor the group. Every student had to ensure traceability of his/her growing knowledge and skills in specific books of 
knowledge such as: the book of inventions and the book of trends. The evaluation of each student in this class is made on two phases: the assessment of the task performed (the book's content and the way that the student presented it), and a common assessment for the entire group for the idea proposed in the final phase of presentation of the innovative mini-project.

\section{Academic Year 2011/2012}

- The bachelor class: Entrepreneurship management

24 students with the same profile as their predecessors of 2010/2011 have followed this course. During this academic year, we have made the following change: Based on the results of Tuning 2009 [3] on the skills expected from the bachelors of Management, we reduced the level of learning outcomes for students of this year compared to master students. This caused a decrease of teaching methods from 9 to 3 and tools from 22 to 10 and a change in the output of the course from the Innovation Feasibility File of an innovative mini-project to an application of a tool or a method of innovation to a product or a service existing on the industries or markets surrounding the University of Annaba such as: hair dryer, ironer, cell phone, glasses, laptop, electric motor and hand watch.

- The master class: Quality and innovation management

25 students from the best of Bachelors of Management of Annaba University were trained. At this year, we have changed the Innovation Feasibility File of an Innovative mini-project to a comparison of two methods of innovation and have applied them to products of industries or markets surrounding the University of Annaba. This enabled us to further training of students to 9 methods and 22 tools of innovation as a supervisor of the groups competition. Students were transformed here to presenters of a course entitled: Comparison of methods and tools for innovation and their application to the product. The choice of the products this year was entirely made by students.

- The master class: Strategic management

Furthermore, 24 students from the best of Bachelors of Management from theUniversity of Annaba were trained. We used the same methodology as for: Quality and Innovation Management Master Class, but with the following improvements: the mini-project of this year was divided into two parts: Innovation and Creativity.

In the innovation part, we asked students to present us on opponent groups of two to three students, a comparison between two methods of innovation and apply them to an existing product in the industries or markets surrounding the University of Annaba. This is the same work as their counterparts of the other Master Class.

In the creativity part, we used the Problem Based Learning Pedagogy for a mini-project which is synchronically treated by their counterparts of EcoleCentrale Paris students. The mini-project was: Development of a system incorporating architectural and urban areas with various functions, with autonomous propulsion and inserted to buildings or to urban or public spaces to park a car.

\section{Academic Year 2012/2013}

- The bachelor class: Entrepreneurship management

The class of this year was composed of 21 students with the same characteristics as their counterparts in the previous two years. They were trained similarly to those of last year 2011/2012. Products that have been objects of study for this year are: eye glasses, hand watch, mobile phone, ironer, hair dryer and coffee making machine.

- The master class: Quality and innovation management

The Class of this year is composed of 17 students with the same characteristics as their counterparts in the previous two years. We made the following changes allowed by the CDbyS model and its changing scenarios. We divided the course in two successive phases: the Innovation phase and the Innovation Management phase. During the first phase, we gave the updated definitions of innovation, then, we showed to students a series of case studies of real innovative projects. In the phase of Innovation Management, we train students to 9 methods and 22 tools of product or service innovation. The novelty of this year is that we have token a single mini-project for five groups of three students each. It is: Mission Impossible, adapted from the movie. We have chosen this theme in order to use the sense of challenge between the competitors to allow them prove the concept of their radical innovation of a product or a service.

We adopted this year, the scale of measurement of innovation given by Professor Bernard Yannou [36], and the proof of concept methodology used in the TV Show "Stars Of Science" on mbc4 [36] (see Fig. 5 and Fig. 6).

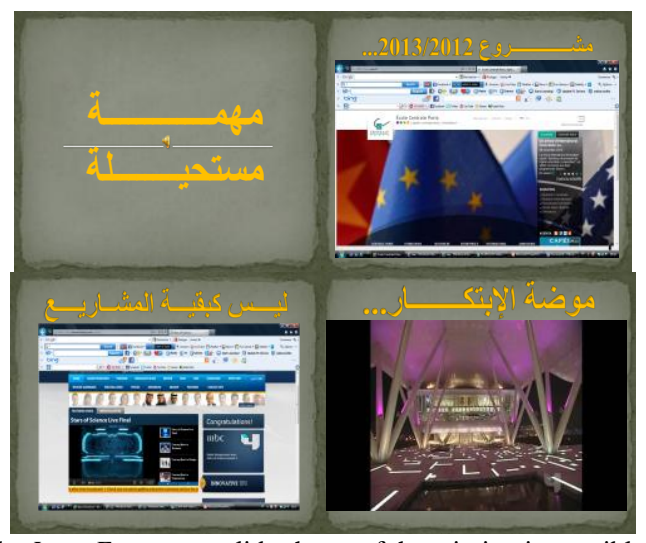

Fig. 5. The InnovEng course slide shows of the mission impossible project ${ }^{1}$.

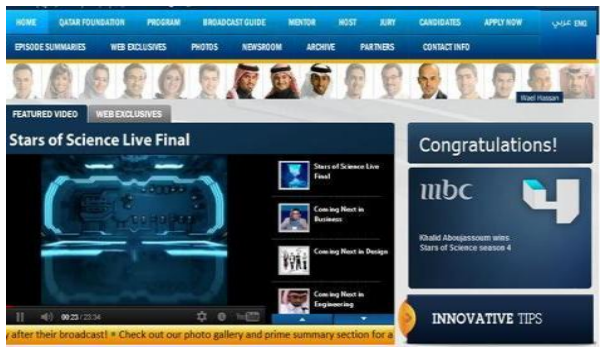

Fig. 6. The official webpage of the TV show stars of science/saison 42012.

The MasterClass: Strategic Management. Not delivered this year.

\section{RESUlts}

\section{A. CDbyS Model}

As a teacher, using $C D b y S$ model transform me from an

${ }^{1}$ Mission Impossible = مشرو ع 2013/2012 مهمة مستحيلة It is not like its predecessors = ليس كبقية المشاريع something = موضة الإبتكار 
information transmitter to a facilitator of a knowledge accumulators. CDbyS model makes it easier for us to achieve our goals by enabling us to adapt to the environment quickly. It allows us to improve the InnovEng course, class after class and year after year. It has led to greater flexibility in the management of educational process either in analysis, design, development, implementation or evaluation phase.

Through this model, we have successfullyobtained an adoption of tools and methods for innovation of products or services by the management students of Annaba university which were intended primarily for engineers, and a greater responsiveness to the uncertain context which the InnovEng course was designed, developed and implemented.

\section{B. InnovEng Course}

With the application of $C D b y S$ model, we have obtained the following results from the InnovEngcourse:

\section{1) A materialized outputs}

\section{Academic Year 2010/2011}

- The bachelor class: Entrepreneurship management

Some of the innovative projects presented by the students this year are: The doll which learn Muslim children how to do a prayer, the amphibian car, the Interactive Puzzle, the babies sleeping cradle, educational video game with $100 \%$ Algerian interface, the innovative toy for the disabled people. The holders of the last two projects have each presented a prototype: the first for a video game designed with a professional software for the development of video games, and the second made on wood with carpenter assistance. The second group visited a center for a disabled people in Annaba andtalked with them. After several visits, they created theconcept after identifying those people's needs (see Fig. 7).

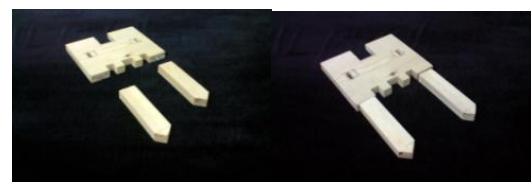

Fig. 7. A prototype made with a wood to explain the innovative toy attended to a disabled people.

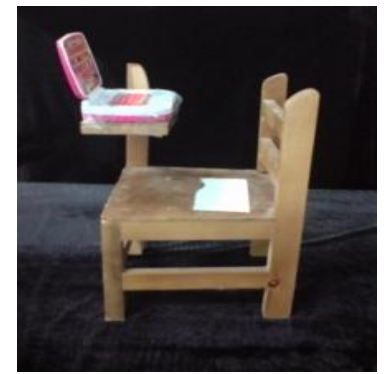

Fig. 8. Intermediary design object shows a concept of a chair attended to a disabled people presented by a student of the master class: quality and innovation management 2010/2011.

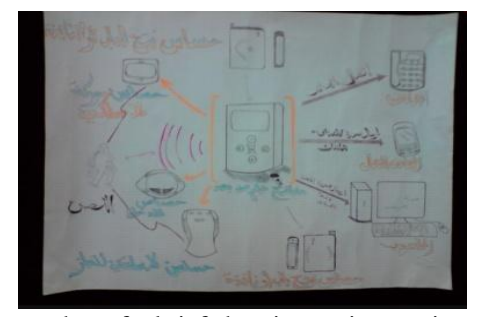

Fig. 9. A snapshot of a brief showing an innovative concept of alarmpresented by two students of the master class: quality and innovation management 2010/20.11.
- The Master Class: Quality and Innovation Management

This year, the students presented to me the following projects: a new packaging of yoghurt, two Innovative office tools, three innovative chairs (see Fig. 8), two innovative alarm concepts. Fig. 9 contains a Brief which represents one of them, and two innovative toys for children. We photographed both Briefs as proof of the toys concept as shown in Fig. 10.

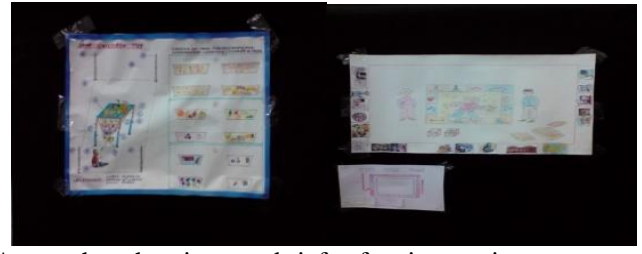

Fig. 10. A snapshot showing two briefs of an innovative concept of children toys presented by two opponent groups of three students each one of the master class: Quality and Innovation Management 2010/2011.

- The master class: Strategic management

Innovative projects presented in this class are: a comfortable chair, a spoon for a newborn, new video game, a new billiard stick, a new toothbrush, a soap box installed in the bathroom and an innovative razor. Fig. 11 shows an outline of this razor concept.

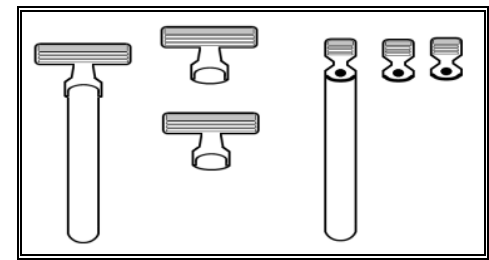

Fig. 11. An outline of a new concept of razor proposed by a group of students of the master class: strategic management 2010/2011.

\section{Academic Year 2011/2012}

- The bachelor class: Entrepreneurship management

Fig. 12 shows a snapshot of a diagram representing a tool for innovation presented by a student in this class.

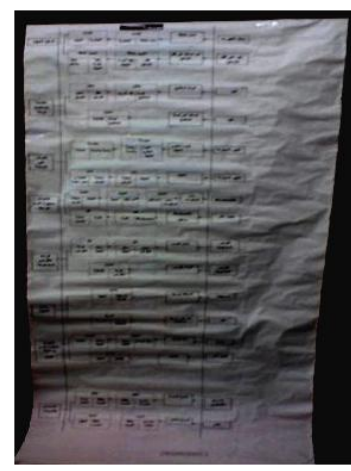

Fig. 12. A snapshot of a diagram representing the functional analysis of a laptop presented by a student of the bachelor class: entrepreneurship management 2011/2012.

- The master class: Quality and innovation management Two best projects presented for this year for a comparison of two tools of innovation and its application to a product brought from the industries and markets surrounding Annaba University. They are: The economic hairdryer project and the cheapest car project.

- The master class: Strategic management

The student presentations were very relevant. Their deepen effortsallowed them to present a high quality of state 
of the art of the project synchronized with their counterparts of EcoleCentrale Paris in the academic year 2011/2012: A development of a system incorporating architectural and urban areas with various functions, with an autonomous propulsion and inserted to buildings, urban or public spaces to park a car.

\section{Academic Year 2012/2013}

Design and Implementation of the course was done for bachelors and only for the Master class: Quality and Innovation Management. For these classes, the theoretical platform and knowledge regarding tools and methods of innovation of a product and a service and RID $^{\circledR}$ was delivered.Students' assessment for that year has not accomplished.

\section{2) An empirical evaluation}

The results of the students per class are like the following:

- The bachelor class: Entrepreneurship management

Academic Year 2010/2011

Highest project rating: 17/20.

Lowest project rating: 10,50/20.

Highest exam rating: 13/20.

Lowest exam rating: 00/20.

The level of this class is fair and Fig. 13 shows us its distribution.

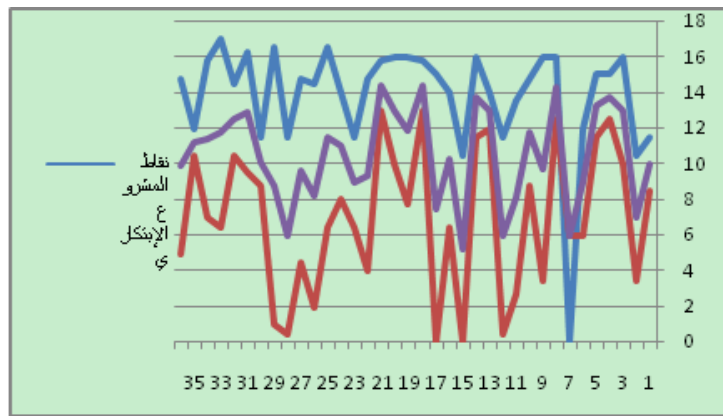

Fig. 13. The distribution of bachelor class $2010 / 2011^{2}$.

Academic Year 2011/2012

Highest project rating:18/20.

Lowest project rating: $13 / 20$.

Highest exam rating: 13/20.

Lowest exam rating: 06/20.

The level of this class is good and Fig. 14 shows us its distribution.

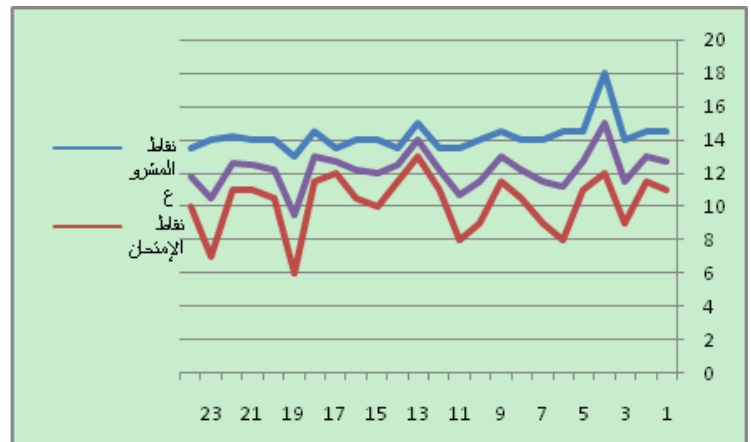

Fig. 14. The distribution of Bachelor Class 2011/2012.

نقاط المشاريع الإبتكارية = نقاط المشروع =

Exam evaluation rating = نقاط الإمتحان = نقان

Course evaluation rating = معدل المقياس
- The master class: Quality and innovation management Academic Year 2010/2011

Highest project rating:17/20.

Lowest project rating: 11/20.

Highest exam rating: $13 / 20$.

Lowest exam rating: 04/20.

The level of this class is good and Fig. 15 shows its distribution.

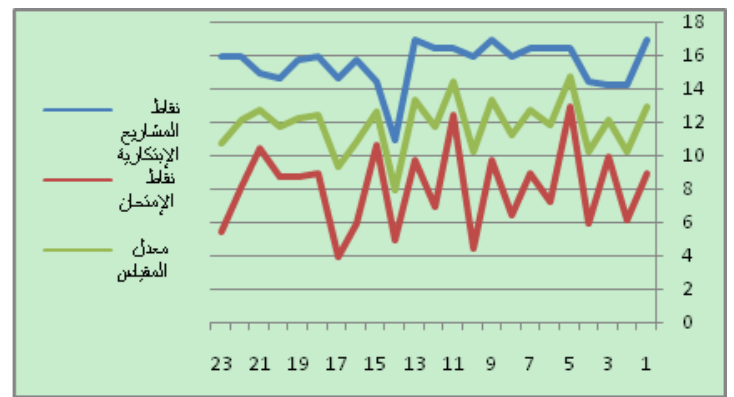

Fig. 15. The distribution of master class QIM 2010/2011.

Academic Year 2011/2012

Highest project rating:15,50/20.

Lowest project rating: 12,50/20.

Highest exam rating: 16/20.

Lowest exam rating: 05,50/20.

The level of this class is good and Fig. 16 shows its distribution.

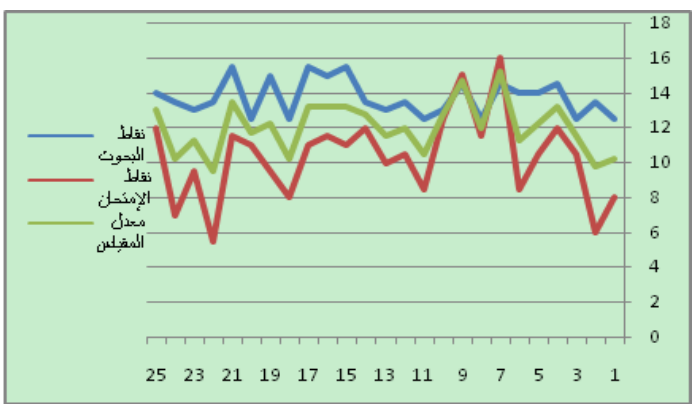

Fig. 16. The distribution of master class QIM 2011/2012.

- The master class: Strategic management

Academic Year 2010/2011

Highest project rating:18/20.

Lowest project rating: 13,50/20.

Highest exam rating: 16,50/20.

Lowest exam rating: 03/20.

The level of this class is good and Fig. 17 shows its distribution.

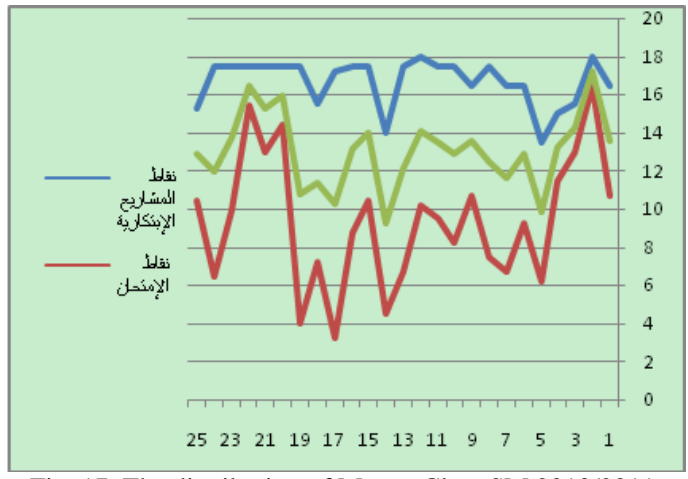

Fig. 17. The distribution of Master Class SM 2010/2011.

Academic Year 2011/2012 
Highest project rating: $18,50 / 20$.

Lowest project rating: $15,75 / 20$.

Highest exam rating: $15,50 / 20$.

Lowest exam rating: 05/20.

The level of this class is good and Fig. 18 shows its distribution.

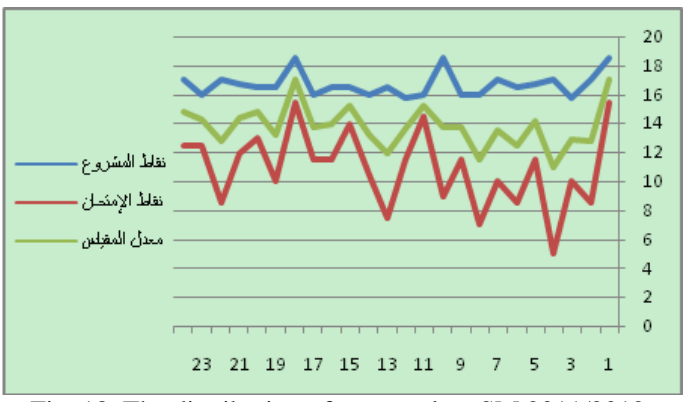

Fig. 18. The distribution of master class SM 2011/2012

\section{3) A qualitative evaluation}

- About students

This experience is enrolled for the management students of Annaba University during 2 years and half. It clearly showedan apparent rush of them on this type of education despite their differences of degrees, specialties and epistemological origins.

Our opinion is that this new material they appeared different from other routine materials consisting of mnemonic methods. The student adhesion for this kind of education is reflected by the results presented from Fig. 13-Fig. 18.

The popularity unprecedented for that course is also due to its novelty, and therefore, one is curious to discover.This material also came to meet the new students' learning preferences, regarding the content or the manner. It has always had a hyper surprising activity of students in this course andahypo activity in other conventional management courses.Based on the results of the Bachelor Class, it was concluded that there is no relationship between the level of students in previous years and during this year, and their ambition perimeter to innovate. Also, it is no relationship between student behavior and his ambition perimeter or his genius. We were surprised to see students as composed a "special class" with a ranking in the previous year or this year very low, they produce an unexpected innovative mini-project vis-à-vis the degree of deepening and effort allowed. They have provided well done and well finished job. They mastered ICT and are more comfortable in communication with others than the majors.

\section{- About the course}

The InnovEng Course is built on new pedagogical approaches such as: project-based learning, problem-based learning, learning through simulation, coaching, mentoring, facilitating, tutoring and animation. The teacher here become a "coach" who's his role is to increase the skills of students to in advance measurable and well defined level.

Skills that the student has increased are: the ability to innovate radically, the supply of new ideas and their implementation on the ground and the learning to demonstrate innovation using the radical innovation scale.

This type of teaching requires a lot of work, a lot of time and effort in preparing lessons and tutorials, or concentration during class to receive ongoing feedback from students and see their reactions continuously. This is a non-stop monitoring of student behavior.

- About the instructional environment

The students' exposure to this type of learning has created probably the change in the educational environment. The student felt the difference between the prevailing climate for teaching this material and other materials. The Management Department classrooms of Annaba University were transformed into workshops to present models and prototypes of products, and the fact that these models and plans are moving in the courtyard and corridors of this department, can allow us to say that the learning environment of this department has changed.

\section{CONCLUSION}

Using CDbyS model make it easier for us to achieve our goals by adapting and adjusting to the environment quickly. It allowsto improve the InnovEng course step by step. It mobilizes a greater flexibility in the management of educational process.

Through this model, we have successfully obtained an adoption of tools and methods forproducts or services innovation by the management students of Annaba University, and a greater reactivity to adjust the educational process to the uncertain context which the InnovEng course has been developed.

Also, this experience clearly showed an apparent rush of the management students on this type of education despite their differences in degrees, specialties and epistemological origins. This shows us that radical innovation has great days on business schools.

We advocate for a widespread adoption of this course on management education and for building a global innovation system multilevel, multi-sector and multi function developed from this course. We can use the general theory of systems to construct it. The adoption of this course allowed the future leaders to become familiar with the design science and to acquire design thinking in their management behavior. This brings them the ability to sustain innovation in their organizations and improve their Radical Innovation Skills.

As it is difficult to generalize the results of one experience at the entire management education, more experiments are needed to validate or not the conclusions of this experience.

\section{ACKNOWLEDGMENT}

I wish to thank Professor Bernard Yannou for the bibliography and for his permission to follow his experiences at EcoleCentrale Paris from October 2008 to March 2010.

My thanks also to LGI Industrial Engineering Laboratory members and CedocDocumentation Center members of EcoleCentrale Paris for their technical assistance during this period.

\section{REFERENCES}

[1] B. Yannou and M. Bigand, "A curriculum of value creation and management in engineering," European Journal of Engineering Education, pp. 1-12, 2004. 
[2] H. Mintzberg, Managers not MBAs! Paris, France: Organisation editions, 2005

[3] Reference Points for the Design and Delivery of Degree Programmes in Business, Tuning Educational Structures in Europe Tuning Project, Universidad de Deusto, Espagne, 2009.

[4] B. Yannou and B. Zimmer, Innovate for the elderly people Application of RID on Gerontechnology, White Book 2011, Paris, France: Ecole Centrale Paris, 2011.

[5] C. Cuisinier, E. Vallet, and B. Yannou, Another Look at Innovation, Paris, France: Logica Business Consulting, 2011.

[6] B. Yannou, "The research in innovation engineering at Centrale," Centralians, no. 608, pp. 38-43, February 2011.

[7] D. Holman, "Contemporary models of management education in the UK," Management Learning, vol. 31, no. 2, pp. 197-217, 2000.

[8] W. Byrt, Management Education an International Survey, New York, USA: Routledge, 1989.

[9] G. Garel and E. Godelier, Teaching Management, Paris, France: Lavoisier,2004.

[10] O. Biencourt, P. Couronne, C. Lagarde, C. L. Corroller, J. L. Pottier, S. Ngomaï, et al., "Report of the working group of the conference of Economics and Management Faculties' Deans and Directors," presented at the conference of Economics and management Faculties' Deans and Directors, Paris, France, 2007.

[11] J. P. Nioche, "The management education deals with the 21st century challenges," French Review of Management, no. 178-179, pp. 1-287, Paris, France: Lavoisier, 2007.

[12] I. Alon and J. McIntyre, Business and Management Education in China, Singapore, Indonesia: World Scientific Publishing Co, 2005.

[13] G. E. Snelbecker, Learning Theory, Instructional Theory, and Psychoeducational Design, USA: McGraw-Hill, Inc, 1974.

[14] C. M. Reigeluth, Instructional Design Theories and Models An Overview of their Current Status, New Jersey, USA: Lawrence Erlbaum Associates, Publishers, 1983.

[15] P. Dessus, "What instructional design models tell us about instruction?"Swiss Review of Educational Sciences, vol. 28, no. 1, pp. 137-157, 2006.

[16] J. F. Bobbitt, TheCurriculum, New York, USA: Arno Press, 1918.

[17] R. M. Gagné and L. J. Briggs, Principles of Instructional Design, New York, USA: Holt, Rinehart, and Winston, 1979.

[18] R. M. Diamond, Designing and Improving Courses and Curricula in Higher Education A Systematic Approach, San Francisco, USA, London, UK: Jossey-Bass Inc., Publishers, 1989.

[19] A. J. Romiszowski, Designing Instructional Systems, London: Kogan Page Ltd, 1981.

[20] R. Brien, Cognitive Science and Education, Québec, Canada: Québec University Press, 1991.

[21] W. Dick, L. Carey, and J. O. Carey, The Systematic Design of Instruction, USA: Pearson Allyn and Bacon, 2005.

[22] Systems Approach to Training (SAT) Manual, United States Marine Corps, Training and Education Command, Virginia, USA, 2004

[23] P. L. Smith and T. J. Ragan, Instructional Design, USA: John Wiley\& Sons Inc, 2005.

[24] C. M. Reigeluth and A. A. Carr-Chellman, Instructional Design Theories and Models Volume3 Building a Common Knowledge Base, New York, USA: Routledge, 2009.

[25] G. S. Edmonds, R. C. Branch, and P. Mukherjee, "A conceptual framework for comparing instructional design models," Educational Technology Research and Development, vol. 42, no. 4, pp. 55-72, 1994.
[26] K. Gustafson, "Instructional Design Models," in International Encyclopedia of Educational Technology, T. Plomp and D. Ely, Ed., Cambridge, UK: Pergamon, 1996, pp. 27-32.

[27] R. A. Braden, "The case for linear instructional design and development a commentary on models, challenges, and myths," Educational Technology, pp. 5-23, March - April 1996.

[28] H. Mintzberg, The Nature of Managerial Work, USA: Harpercollins College Div,1973.

[29] B. Yannou, Ariane reform at the Ecole Centrale Paris, N. Mehddeb, Interviewver, December 2008.

[30] ARIANE Project at Ecole Centrale Paris What Third Years at Ecole Centrale Paris?Ecole Centrale Paris, Châtenay-Malabry,France: Internal Document, February 2008.

[31] Ecole Centrale Paris. (October 2008). Centralians Curriculum. [Online]. Available: http://www.ecp.fr, http://www.ecp.fr

[32] V. Krishnan, S. D. Eppinger, and D. E.Whitney, "A model-base framework to overlap product development activities," Management Science, vol. 43, no. 4, pp. 437-451, 1997.

[33] C. H. Loch and C. Terwiesch, "Communication and uncertainty in Concurrent Engineering," Management Science, vol. 44, no. 8, pp. 1032-1048, 1998.

[34] D. W. Unger and S. D. Eppinger, "Comparing product development process and managing risk," International Journal of Product Development, vol. 8, no. 4, pp. 382-402, 2009.

[35] N. Mehddeb, "An application of RID on management education," presented at the International Conference on Innovation and Engineering Management IEM 2014, Monastir, Tunisia, March 22-25, 2014.

[36] B. Yannou, B. Zimmer, R. Farel, M. Jankovic, and J. S. Le Cardinal, "Proofs of utility, innovation, profitability and concept for innovation selection," in Proc. 19th International Conference on Engineering Design-Design for Harmonies, vol. 9, Seoul, Korea,2013, pp. 377-388.

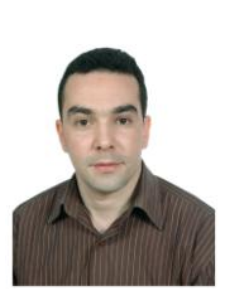

Nabil Mehddeb was born on $29^{\text {th }}$ of September, 1980 in Annaba, Algeria. He obtained a bachelor in management sciences from Annaba University, Algeria in 2001, and Magister in management from Biskra University, Algeria, 2004. He is pursuing PhD in the field of Managementfrom Annaba University, Algeria

He has worked as a maître-assistant at Annaba University from 2004 to 2012. Currently, he is the head of Department of Economical Environment, Algiers Management School, Algeria. His research interested was focus on the improvement of Management Education, Process Improvement, Systems Design and Steering, Radical Innovation for non-engineers which appears as, N Mehddeb, "An Application of Value Analysis in Algeria: Presentation of a Case Study", La Valeur, no. 99, May 2004. N. Mehddeb,"Application de 1'Analyse de la Valeur en Algérie: Etude de Cas", La Valeur, No. 99,Mai 2004. And N. Mehddeb,"An Application of RID on Management Education", presented at the International Conference on Innovation and Engineering Management IEM 2014, Monastir, Tunisia, March 22-25, 2014,"to be published".

Mr. Mehddeb was adherent to the French Society for Value Analysis "Association Française pour l'Analyse de la Valeur AFAV". He introduced for the first time worldwide the Innovation Engineering discipline and Radical Innovation Design RID ${ }^{\circledR}$ to the Management Education. 